\title{
Sprawozdanie i reminiscencje z 12. Ogólnopolskiej Konferencji Psychoonkologicznej
}

\author{
Justyna Pronobis-Szczylik \\ Warszawski Ośrodek Psychoterapii i Psychiatrii
}

Psychoonkologia 2015, 3: 125-127

DOI: $10.5114 /$ pson.2015.57173

W dniach 17-19 września 2015 r. w Gdańsku odbyła się 12. Ogólnopolska Konferencja Psychoonkologiczna organizowana niezmiennie przez Polskie Towarzystwo Psychoonkologiczne. Tegorocznym tematem była rola psychoonkologii $\mathrm{w}$ strategii walki z rakiem $\mathrm{w}$ Polsce oraz problematyka życia po przebytej chorobie.

Od pewnego czasu odnotowujemy coraz większą skuteczność i dostępność terapii onkologicznych. Okres 5 lat bez objawów choroby uznaje się za stan wyleczenia. Cieszy to, że wyleczenie w chorobie nowotworowej zdarza się coraz częściej. Dlatego jest zrozumiałe, że psychologiczne problemy osób po przebytej chorobie nowotworowej oraz jakość życia pacjentów z chorobą nowotworową są przedmiotem zainteresowania nas wszystkich - zarówno pacjentów, jak i klinicystów. Problematykę tę poruszyły prof. Nina Ogińska-Bulik, która przedstawiła badania dotyczące zasobów osobistych w rozwoju po traumie, oraz prof. Helena Wrona-Polańska, mówiąca o mechanizmach powrotu do zdrowia osób po transplantacji szpiku. Z kolei prof. Marzena Samardakiewicz przedstawiła problemy osób po chorobie nowotworowej przebytej w dzieciństwie, a prof. Mikołaj Majkowicz - badania dotyczące przesłanek oceny jakości życia u pacjentów.

$\mathrm{W}$ tym roku mieliśmy zaszczyt spotkać się z wyjątkową osobą - gościem honorowym konferencji był ksiądz dr Jan Kaczkowski, którego nadzwyczajna postać $\mathrm{w}$ tak zwyczajnym ludzkim, serdecznym wydaniu jest inspiracją do pracy dla nas wszystkich. Wyrazom wdzięczności, uznania i prośbom o wspólne zdjęcie nie było końca. To między innymi dzięki takim ludziom zmienia się stosunek do choroby nowotworowej. Coraz wyraźniej zauważamy tendencję do traktowania raka jako choroby przewlekłej.

Zmiany na lepsze w zakresie długości życia $\mathrm{z}$ chorobą oraz po chorobie niosą ze sobą oczekiwa- nia dotyczące lepszej jakości życia. Nie dziwi więc wzrost zainteresowania różnymi formami pomocy i interwencji psychologicznej. Wśród metod dostępnych dla pacjentów coraz większym zainteresowaniem cieszy się pomoc psychoterapeutyczna. Również uczestnicy konferencji z zadowoleniem przyjęli zaproponowaną przez organizatorów tematykę dotyczącą interwencji psychoterapeutycznej oraz dotąd niepodejmowany temat superwizji.

Tymczasem z doniesień z badań wynika, że rośnie znaczenie immunoonkologii, tzn. leczenia nowotworów przez aktywizowanie układu odpornościowego. Leczenie to polega na odblokowaniu lub rewitalizacji niesprawnych funkcji układu odpornościowego. Nie jest więc ukierunkowane na zwalczanie komórek nowotworowych, ale raczej na wzmocnienie aktywności przeciwnowotworowej poprzez przekazywanie sygnału w obrębie komórek układu odpornościowego. Czy więc w niedalekiej przyszłości - analogicznie do języka biologii molekularnej - będziemy też mogli mówić o immunopsychoterapii? Wiemy przecież z badań, że skuteczność psychoterapii wyraża się obniżeniem poziomu lęku i objawów lękowych, bo pacjent uczy się m.in. zauważać i regulować swój lęk, a to skutkuje niższym wskaźnikiem depresji i poprawą jakości życia. Z kolei z innych badań wynika, że umiejętność regulowania lęku w zdrowy sposób oraz samo zajmowanie się własnym lękiem - w odróżnieniu od nawyku ignorowania go - powoduje obniżenie poziomu lęku i pozwala na zredukowanie stanu hiperaktywności $w$ ciele pacjenta. Jednocześnie istnieją dowody naukowe potwierdzające, że wysoki poziom lęku pogarsza funkcjonowanie układu odpornościowego (badania Schulkin-Allostasis).

Liczba osób uczestniczących w warsztatach i bardzo żywy udział w dyskusjach wskazuje, że wybór psychoterapii jako tematu wiodącego 12. Ogólnopolskiej Konferencji Psychoonkologicznej był nie-

Justyna Pronobis-Szczylik, psycholog kliniczny, psychoterapeuta psychodynamiczny, psychoonkolog, Warszawski Ośrodek Psychoterapii i Psychiatrii, www.osrodekpsychoterapii.com.pl; e-mail: justyna.pronobis.szczylik@gmail.com 
zwykle trafny. Duże zainteresowanie uczestników, głównie praktyków, klinicystów, budziła metodologia pracy z chorymi, czyli sesje warsztatowe, podczas których można było zapoznać się z konkretnymi modalnościami w psychoterapii i konkretnymi narzędziami pracy psychoterapeutycznej z chorymi na raka. Wiele osób wzięło udział w warsztatach „Psychoterapia w zaawansowanym raku i teoria poczucia sensu życia Victora Frankla w rozumieniu psychodynamicznym" Justyny Pronobis-Szczylik, a także w dwóch warsztatach Mariusza Wirgi "Pięć życzeń osoby umierającej” i "Grupowa CBT - problemy egzystencjalne, śmierci i umierania”. Z dużym uznaniem spotkało się wystąpienie na temat wsparcia psychoterapeutycznego po przebytej chorobie dr Joanny Zapały, twórczyni 10-latki "Akademii Walki z Rakiem", oraz na temat terapii poznawczo-behawioralnej kobiet $\mathrm{z}$ rakiem piersi dr Ewy Wojtyny. Na uwagę zasługuje również praca na temat propagowanego - także w standardach postępowania IPOS - sposobu pomocy, jakim jest mindfulness, z zastosowaniem ćwiczeń praktycznych, przygotowana przez Annę Borzeszkowską, Dorotę Grabowską i Izabelę Malicki. Warto wyróżnić też prezentację dotyczącą chorych na raka, którym towarzyszą zaburzenia psychiczne. Pracę o tym, jak zadbać o osoby szczególnie bezradne, przygotował zespół w składzie: Dorota Gołąb, Maria Kuśnierkiewicz, Marta Zagozda, Monika Smólska i Joanna Jaroszyk-Pawlukiewicz.

W dyskusji pojawiło się pytanie, kto ma pełnić funkcję psychoonkologa. Argumenty przemawiają za tym, aby pomocy psychoonkologicznej udzielała osoba mająca doświadczenie i wykształcenie psychologiczne, a jeszcze lepiej - psychoterapeutyczne. Dlatego ważne jest, aby do praktyki psychoonkologicznej trafiały osoby $\mathrm{z}$ odpowiednim przygotowaniem.

Podczas tegorocznej konferencji ogromnym zainteresowaniem cieszyło się zagadnienie superwizji psychoterapeutycznej w psychoonkologii przygotowana przez dr. Marcina Jabłońskiego, jak również superwizja grupowa dla psychoonkologów prowadzona przez dr Joannę Kozakę i dr Martę Porębiak.

Inspirująca dla wielu uczestników okazała się wymiana doświadczeń w obszarze funkcjonowania opieki psychoonkologicznej za granicą. Dużym powodzeniem cieszył się wykład dr. Mariusza Wirgi, który przybliżył realia psychoonkologii w USA oraz mówił o zachowaniach prozdrowotnych. Gościliśmy także Franciscę Romito, która przedstawiła sytuację psychoonkologii we Włoszech. O psychoonkologii na Litwie mówiła Janina Buterleviciute, a na Ukrainie - Yaroslav Chulovsky.

Poruszono temat zmiany stylu życia, która wpływa na zmniejszenie ryzyka zachorowania na nowo- twory, oraz zaleceń europejskiego kodeksu walki $\mathrm{z}$ rakiem $\mathrm{w}$ aspekcie praktycznym.

$\mathrm{Na}$ gruncie polskim potrzebę integracji i model całościowej opieki onkologicznej z uwzględnieniem roli psychoonkologii ukazał prof. Jacek Jassem, kierownik Katedry i Kliniki Onkologii i Radioterapii Gdańskiego Uniwersytetu Medycznego, prezentując stworzony przez siebie i zespół onkologów cancer plan.

Zespół prof. Krystyny de Walden-Gałuszko, Piotra Mroza, Leszka Pawłowskiego i Pawła Zielaznego przedstawił stan opieki psychologicznej i psychoonkologicznej w placówkach onkologicznych oraz w jednostkach opieki paliatywnej i hospicyjnej w Polsce. Obraz ten został wzbogacony także o perspektywę chorych. Odbyły się dwie sesje organizowane przez Polską Koalicję Pacjentów Onkologicznych.

W konkursie 12. Ogólnopolskiej Konferencji Psychoonkologicznej na najlepszy plakat zwyciężyła praca „Wzrost potraumatyczny a jakość życia u osób z chorobą nowotworową" autorstwa Joanny Kozaki i Agnieszki Just z Instytutu Psychologii Uniwersytetu Gdańskiego. Drugie miejsce przypadło w udziale Karolinie Faber i Natalii Jach-Salamon z Uniwersytetu Marii Curie-Skłodowskiej w Lublinie za plakat "Kompetencje społeczno-emocjonalne dzieci z chorobą nowotworową", a trzecie miejsce zespołowi: Joanna Król, Anna Kołodziejska, Agata Milik, Małgorzata Kulik, Maria Ligocka, z Uniwersytetu Szczecińskiego, Zachodniopomorskiego Centrum Onkologii w Szczecinie i Centrum Interwencji Kryzysowej PCK w Gdańsku za plakat „Kształtowanie perspektywy temporalnej mężczyzn jako aspekt poziomu przystosowania do choroby nowotworowej". Zwycięzcom konkursu gratulujemy, zachęcając do dalszej twórczej aktywności naukowej.

Uroczysta kolacja, która w poprzednich latach zwykle budziła ducha zabawy i tańca, tym razem upłynęła na rozmowach i dyskusjach, serdecznych spotkaniach i pielęgnowaniu przyjaźni - wartościowych, pełnych znaczenia doznaniach, tak bardzo potrzebnych i pożądanych, bo umacniających więzi między nami i sprawiających, że tęsknimy do następnego spotkania.

Dziękujemy Organizatorom nie tylko za doświadczenia poznawcze i edukacyjne, lecz także wspaniałą gościnność oraz nieustanne wzmacnianie środowiska Towarzystwa i jego członków. To jest właśnie to, czego w niełatwej pracy psychoonkologa bardzo potrzebujemy.

Składamy podziękowania pani prof. Krystynie de Walden-Gałuszko, przewodniczącej obu komitetów konferencji, naukowego i organizacyjnego, przez niektórych nazywanej aniołem polskiej 
psychoonkologii, za nadanie ducha wydarzeniom, które są naszym udziałem, gdy przyjeżdżamy na konferencję do Gdańska z całej Polski.

$\mathrm{W}$ tym roku ducha tego wydarzenia zawdzięczamy także licznym wolontariuszom, których znakomita praca organizacyjna uczyniła konferencję oraz pobyt w urzekającym Gdańsku i w Polskiej Filharmonii Bałtyckiej jeszcze przyjemniejszymi. 